\title{
NAPIĘCIE MIĘDZY ŚWIECKOŚCIĄ I SAKRALNOŚCIĄ W WIZJI WŁADCY W DE VITA CONSTANTINI EUZEBIUSZA Z CEZAREI
}

Aktualność jakiejś postaci historycznej mierzy się zazwyczaj ilością studiów, jakie w ciągu ostatniego roku, czy w jakimś bliskim nam okresie czasu, pojawiają się na jego temat. W tym znaczeniu Euzebiusz z Cezarei jawi się jako postać niezwykle aktualna, i to nie tylko jako „ojciec historii Kościoła” ${ }^{1}$, dzięki slawnemu dziełu, jakim jest Historia ecclesiastica. Świadczą o tym również nowe wydania rozmaitych jego licznych pism oraz ich thumaczenia na różne języki, a także studia poświęcone jego myśli, mimo że wciąż brakuje jakiegoś syntetycznego dziela, które ukazałoby jego pełne znaczenie teologiczne i historyczne dla epoki, w której żył oraz wpływ, jaki wywarł w ciągu wieków. Studia, jakie podjęto nad Euzebiuszem w ciągu ostatnich stu pięćdziesięciu lat, zwłaszcza te sytuujące się $\mathrm{w}$ ramach poszukiwania politycznego znaczenia religii chrześcijańskiej, pozwoliły uznać go za autora „pierwszej teologii politycznej chrześcijaństwa"2. Wprawdzie na Zachodzie teologia ta wywierała swój wpływ głównie w IV wieku, gdyż Kościół zachodni bardzo szybko i w zdecydowanym stopniu zdominowala teologia św. Augustyna, to jednak na Wschodzie stała się - według określenia Hendrika Berkhofa - „tkanką i krwią" tamtejszego Kościoła. ${ }^{3} \mathrm{Ma}$ ona decydujące znaczenie choćby dla zrozumienia wschodniego ujęcia problemu relacji między Kościołem i państwem, łącznie z kwestią tak zwanego „cezaropapizmu”, bez względu na to, czy uznamy go za jego twórcę czy też nie ${ }^{4}$. Szkoda, że w polskich studiach problem ten jest dotychczas praktycznie nieobecny.

\footnotetext{
${ }^{1}$ Por. Euzebiusz z Cezarei Palestyńskiej, SWP s. 143.

${ }^{2}$ Por. R. Farina, L'impero e imperatore cristiano in Eusebio di Cesarea. La prima teologia politica del Cristianesimo, Zürich 1966.

${ }^{3}$ Dzieła tego autora nadal posiadają podstawowe znaczenie w kwestii interpretacji pism Euzebiusza, por. H. Berkhof, Die Theologie des Eusebius von Cäsarea, Amsterdam 1939; Kirche und Kaiser. Eine Untersuchung der Entstehung der byzantinischen und der theologischen Staatsauffassung im vierten Jahrhundert, Zürich 1947.

4 Por. J.M. Sansterre, Eusèbe de Césarée et la naissance de la théorie "césaropapiste», „Byzantion" 42 (1972) 131-147.
} 


\section{EUZEBIUSZ Z CEZAREI I TEOLOGIA POLITYCZNA}

Teologia polityczna została sformułowana przez Euzebiusza w pismach, które możemy określić mianem „konstantyńskich”; chodzi tutaj głównie o De vita Constantini, De laudibus Constantini. Jest ona także obecna w innych jego dzielach, a zwłaszcza w: Historia ecclesiastica, Praeparatio evangelica i Demonstratio evangelica. Ta wszechstronna obecność kwestii konstantyńskiej w dzielach Euze'iusza jest niewątpliwym wyrazem zafascynowania cesarzem, którego przełomowych dzialań był naocznym świadkiem. Zdawał sobie sprawę z rzeczywistego „przelomu”, w jakim dane mu bylo żyć - przełomu dokonującego się za sprawą Konstantyna ${ }^{5}$. Ten fakt nie dziwi tym bardziej, że cesarz ten - mimo rozmaitych krytyk podnoszonych pod jego adresem - nie przestaje fascynować i dzisiejszycl badaczy starożytności ${ }^{6}$.

W niniejszym opracowaniu zwracam uwagę tylko na dzieło De vita Constantini. Zanim przejdziemy do lektury niektórych jego wątków warto zwrócić uwagę na ważniejsze opinie wyrażone na temat tego dziela, które wskazują na to, $\mathrm{z}$ jakim typem opracowania mamy tutaj do czynienia i uprzedzają pewne trudności, jakie możemy mieć z jego interpretacją. Luigi Tartaglia słusznie zauważa: „Życie Konstantyna nie jest dziełem, w którym można zakochać się po pierwszym przeczytaniu"? . Rafaele Farina, wybitny znawca Euzebiusza, w swoim fundamentalnym studium na temat jego teologii politycznej, stwierdza: „Pierwsze wrażenie, jakie wzbudza De vita Constantini, przede wszystkim u dzisiejszego czytelnika [...] nie należy do najlepszych" ${ }^{8}$. Te sądy opierają się na fakcie, że dzisiaj dystansujemy się od panegiryków - przynajmniej w dziedzinie poważnej historiografii, co nie oznacza, że ten gatunek literacki należy tylko do przeszłości - podczas gdy Euzebiusz - nie całkiem słusznie - został nazwany przez Burckhardta „najbardziej odrażającym z panegirystów”9. Mimo tych zastrzeżeń, po uważnej lekturze, De vita Constantini może okazać się dziełem pasjenującym, jeśli czyta się je w perspektywie jego przestania teologicznego. Poza tym sam Euzebiusz podpowiada nam, że zamierza napisać książkę „użyteczną i konieczną" ", i za taką rzeczywiście może być uznana w perspektywie znaczenia, jakiego nabrała.

${ }^{5}$ Por. G. Bonamente, La «svolta costantinina», w: Chiesa e Impero. Da Augusto a Giustiniano, red. E. Dal Covolo - R. Ugolione, Roma 2001, 145-170.

${ }^{6} \mathrm{Z}$ nowszych opracowań dotyczących Konstantyna, por. P. Keresztes, Constantine. A Great Christian Monarch and Apostel, Amsterdam 1981; T. D. Barnes, Constantine and Eusebius, Cam. bridge Mass. - London 1981; tenże, Athanasius and Constantinus. Theology and Politics in the Constantinian Empire, Cambridge Mass. - London 1993; Th. Grünewald, Constantinus Maximus Augustus. Herrschaftspropaganda in der zeitgenossischen Überlieferung, Stuttgart 1990.

${ }^{7}$ L. Tartaglia, Introduzione, w: Eusebio di Cesarea, Sulla vita di Costantino, Napoli 1984, 22.

${ }^{8}$ Farina, L'impero e imperatore, s. 18.

9 J. Burckhardt, L'età di Costantino Grande, Roma 1970, 322 (oryginal niem. Die Zeit Constantins Grossen, Leipzig 1853). 


\section{DE VITA CONSTANTINI - GATUNEK LITERACKI I TRESĆ}

By móc odczytać przesłanie Euzebiusza z De vita Constantini, jest przede wszystkim konieczne określenie gatunku literackiego tego dzieła, bądź też wskazanie różnych gatunków literackich, $\mathrm{z}$ których jest skomponowane. Wydaje się, że należy zgodzić się w tej kwestii z R. Fariną, który stwierdza, że "charakter dziela jest całkowicie szczególny"11, a mianowicie jest to równocześnie biografia, panegiryk i idealizacja. Nie jest to jednak biografia tylko historyczna, ani nie jest to tylko panegiryk, w którym wszystko zostaje podporządkowane normom retorycznym; nie ma w tym dziele tylko „amplifikacji” właściwej dla mów pochwalnych, ale jest „coś jakby przekształcenie religijne postaci władcy" ${ }^{2}$. De vita Constantini ma więc wątek biograficzny, ale wpisany integralnie w eukomion, czyli w ramy pieśni pochwalnej, jak chce Sokrates i Focjusz, ściśle związany z panegirykiem cesarskim, jak chce Menander. Wydaje się, że w świetle tych uwag, trzeba uznać Życie Konstantyna za dzieło zlożone i szczególne, ale równocześnie mające dobrze określony cel „teologiczny", lub - mówiąc ściślej - „ideologiczny”.

Wątek przewodni dzieła stanowią oczywiście wydarzenia historyczne, które znamy także na podstawie innych „historii”, chociaż ich dobór podporządkowany celom, jaki wyznaczył sobie autor, nie ulega wątpliwości ${ }^{13}$. Po dhugim wprowadzeniu (I 1-11), Euzebiusz poświęca kilka stron wspomnieniu Konstancjusza, ojca Konstantyna, i nawiązuje do niektórych wątków z życia samego Konstantyna $z$ okresu przed przejęciem przez niego władzy (I 12-24). Opowiada więc na przykład o pierwszych jego zasługach dla chrześcijaństwa na Zachodzie po zwycięstwie nad Maksencjuszem (I 26-48). Zwraca jednak także uwagę na Wschód, gdzie giną dwaj wielcy prześladowcy Galeriusz i Maksymin oraz zapowiada koniec Licyniusza (I 49-59).

Księga II zawiera opis slynnego zwycięstwa Konstantyna nad Licyniuszem $^{14}$ i pierwszego prawodawstwa chrześcijańskiego dla Wschodu (II 1-60). W międzyczasie rozpoczyna się konflikt między biskupem Aleksandrem i Ariuszem, który władca stara się załagodzić swoimi pismami i przez pośredników (II 61-73).

Księga III rozpoczyna się od opisu przeciwieństwa między władcą chrześcijańskim i prześladowcami (III 1-3), gdzie zostaje opisany przebieg Soboru Nicejskiego, w zestawieniu $\mathrm{z}$ dwudziestoleciem panowania cesarza. Jest to

${ }^{10}$ Por. De vita Constantini I 10, 2.

" Farina, L'impero e imperatore, s. 19.

12 Tanize.

${ }^{13}$ Por. S. Calderone, Storia e teologia in Eusebio di Cesarea, w: Chiesa e Impero, dz. cyt., s. 171-184.

${ }^{14}$ Por. F. Corsaro, Sogni e visioni nella teologia della vittoria e Licinio, „Augustinianum” 29 (1989) 333-349. 
jakby obchód zwycięstwa chrześcijaństwa i cesarza nad nieprzyjaciółmi pokoju (III 4-24). Zostają tu także wymienione inne zasługi Konstantyna dla Kościola, jak: budowanie bazylik, walka z pogaństwem, czy też rozwiązanie problemu heretyków (III 64-66).

Pierwsza część IV księgi opowiada o tym, co Konstantyn uczynił dla państwa (IV 1-7), dla chrześcijaństwa poza cesarstwem (IV 8-14) i dla prawodawstwa chrześcijańskiego w cesarstwie (IV 15-39). W drugiej jej części jest mowa o obchodach trzydziestolecia panowania, które zostają zwieńczone konsekracją Bazyliki Świętego Grobu. Obchody te miały wyjątkowy charakter, chociaż zostały zakłócone niezgodą religijną, która - mimo napomnień cesarza - na nowo spowodowała podział w Kościele. Wspomniany też zostaje problem wojny z Persami. Na końcu cesarz choruje, przyjmuje chrzest i umiera w dzień Pięćdziesiątnicy 337 roku. Jego zwłoki zostają złożone w monumentalnym sarkofagu, który zostal przygotowany w Bazylice Apostołów w Konstantynopolu. Euzebiusz podsumowuje tryumfalnie, że Konstantyn był najbardziej religijnym spośród władców, jacy kiedykolwiek żyli (IV 40-75).

Ta treść niejako „materialna” Życia Konstantyna jest ściśle powiązana $\mathrm{z}$ treścią „idealną", która stanowi niejako właściwe założenie dzieła. Euzebiusz jasno określił cel swojej pracy:

„Celem niniejszego dzieła jest mówienie i pisanie tylko tego, co odnosi się do "pobożnego» życia Cesarza. Ponieważ jednak, także ta materia jest nieskończona, chcę wybrać - z tego, co zostało nam przekazane - tylko to, co jest najbardziej odpowiednie dla naszego celu i najbardziej godne tego, by zostało przekazane potomnym, a także to, co może dać - na ile to możliwe - zwarty wykład"15.

Według tego założenia, Konstantyn zostaje ukazany jak wyzwoliciel chrześcijan, tak jak Mojżesz, który był wyzwolicielem Żydów: cesarz zostaje więc od razu nazwany „nowym Mojżeszem” (I 12.38). Do takiego zadania został wybrany przez Boga i to zadanie przez swoje działania jako władca wypełnit do końca $^{16}$.

Nie będąc jeszcze chrześcijaninem, Konstantyn był zachwycony chrześcijaństwem i pod wieloma względami sprzyjał jego wzrostowi. Pomyślność Kościoła była dla niego najlepszą gwarancją pomyślności cesarstwa (II 65). Z tego też powodu troszczył się o jedność Kościoła, gdyż w przeciwnym wypadku byłby on głównym źródłem niezgody państwowej. Dlatego również stał się gorliwym strażnikiem jego jedności, zarówno wobec pojawiających się herezji, jak i w czasie pokoju. Interesował się także kwestiami wewnętrznymi Kościoła, mając przede wszystkim na względzie jego dobro.

${ }^{15}$ De vita Consantini. I 11, 1-2, PG 20, 924CD.

${ }^{16}$ Por. M.J. Hollerich, Myth and History in Eusebius' "De vita Constantini" $(1,12)$ in its contemporary Setting, „Harvard Theological Review” 82 (1989) 421-445. 
Wzniosła godność wyzwoliciela i obrońcy Kościoła sprawiła, że dla Euzebiusza jego postać jawi się w perspektywie głębokiej „przemiany”: cesarz jawi mu się w całkowicie nowym świetle, jako władca przekraczający swoimi czynami czasy, w których przyszło mu rządzić. Jego troska o cześć dla Boga, sprzyjanie Kościolowi, szacunek dla Pisma św. i doktryny chrześcijańskiej, a także budowanie świątyń, musiały wywierać duże wrażenie na Euzebiuszu, ponieważ było to coś nowego w stosunku do dotychczasowych dziejów chrześcijaństwa, które przecież znał bardzo dobrze, a które nie mogły być uznane za pozytywne. Dostrzegał on także rozmaite cienie w postaci i działaniach cesarza, o czym również wspomina ${ }^{17}$, ale fakt, że ich szerzej nie opisuje, można mu wybaczyć, ponieważ bliskość i niezwykłość opisywanych wydarzeń oraz osobiste przywileje, jakie otrzymał od cesarza, uniemożliwiały sąd w pełni obiektywny.

\section{PODSTAWY TEOLOGICZNE KONCEPCJI EUZEBIUSZA}

Jeśli chodzi o koncepcję władcy, jaką prezentuje Euzebiusz, trzeba przede wszystkim stwierdzić, że opiera się ona na szerokich interpretacjach biblijnoteologicznych, których osnowę stanowi teologia trynitarna oraz teologia Królestwa Bożego. ${ }^{18} \mathrm{Te}$ interpretacje zostały najpetniej przedstawione w De laudibus Constantini, niemniej jednak De vita Constantini jest wystarczające do tego, by ukazać zasadniczy zarys jego koncepcji teologicznej. Koncepcje tę można sprowadzić do następującego paralelizmu: cesarstwo jest „obrazem eikon" Królestwa Ojca, a cesarz jest „naśladowcą - mimesis” Logosu-Króla. Eikon ma charakter ontologiczny i ma za podmiot Boga, a za przedmiot Królestwo. Bóg stwarza cesarstwo ziemskie na obraz swojego Królestwa niebieskiego. Mimesis ma charakter przede wszystkim moralny: obejmuje pojęcie „obowiązku” oraz ma za podmiot cesarza, a za przedmiot Boga, czy też raczej Logos-Chrystusa.

1. Cesarstwo ziemskie jako eikon Królestwa niebieskiego. Cesarz, wybrany suwerennie przez Boga - Władcę Królestwa niebieskiego - do przejęcia instytucji, której został obrany głową, czyli cesarstwa ziemskiego, jest obrazem Władcy niebieskiego ${ }^{19}$. Powinien więc starać się odtworzyć w sobie cechy charakterystyczne i cnoty Władcy niebieskiego, by stać się Jego możliwie najwierniejszym obrazem. Innymi słowy - Bóg stwarza obraz Królestwa niebie-

${ }^{17}$ Por. De vita Constantini II 6, 6; IV 54 .

${ }^{18}$ Ważne uwagi dogmatyczne na ten temat można znaleźć w fundamentalnym dziele Erika Petersona Der Monotheismus als politisches Problem z 1935 roku, por. E. Peterson, Theologische Traktate, Würzburg 1994, 23-81 (Ausgewählte Schriften, Bd. 1); Y. Congar, Le monothéisme politique de l'Antiquité et le Dieu-Trinité, „Concilium” (franc.) 163 (1981) 51-58.

${ }_{19}$ Por. De vita Constantini I 24. 
skiego, a cesarz ma odtwarzać w sobie obraz Władcy niebieskiego. Ta wzajemna więź i kryjące się w niej zobowiązanie ma swoje pierwotne źródło w Bogu. Cesarstwo ziemskie zostaje stworzone przez Logos jako eikon Królestwa niebieskiego. Elementem konstytutywnym tego obrazu jest Boskie pochodzenie władcy: Bóg Ojciec jest źródłem wszelkiej władzy, Logos jest twórcą cesarstwa na obraz Ojca i Jego królowania. Cesarstwo jest więc obrazem Królestwa, a cesarz obrazem $\mathrm{Ojca}^{20}$.

Realizacja tego obrazu ma swój kluczowy punkt w teologii Wcielenia, gdyz przez nie dokonuje się przekazanie przez Ojca władzy Chrystusowi, a przez Chrystusa - cesarzowi. Królestwo Ojca jest urzeczywistniane za pośrednictwem rządów Logosu-Chrystusa, który na obraz Królestwa niebieskiego tworzy cesarstwo ziemskie, by panować nad ludźmi. Cesarstwo ziemskie staje się więc poprzez Wcielenie Logosu obrazem Królestwa niebieskiego ${ }^{21}$.

Ważnym elementem w teologii Euzebiusza jest wprowadzenie ścisłej relacji między monoteizmem i cesarstwem monarchicznym. Jak jest jeden Bóg, którego władca jako taki odtwarza obraz, może być tylko jeden władca. Jak jest jedyność w naturze Bożej, tak jedyność należy również do natury cesarstwa. Jeden Bóg - jedno chrześcijaństwo - jedno cesarstwo - jeden władca chrześcijański: taka jest najbardziej zasadnicza idea w teologii politycznej Euzebiusza, która determinuje wszystkie jego interpretacje. W uprzywilejowany sposób ta idea zostaje wyrażona przez częste stosowanie w odniesieniu do cesarza tytułu autokrator $^{22}$. Zdaje się on być w pełni przekonany, że zarówno monoteizm, jak i monarchia należy właściwie i metafizycznie do natury cesarstwa. Uzasadnieniem dla tej idei jest uznanie cesarstwa za jedyny i uniwersalny organizm, wyrażany poprzez zastosowanie do niego pojęcia „ciała"23.

Celem ustanowienia cesarstwa jest doprowadzenie do utożsamienia uniwersalności de iure Królestwa Chrystusowego $z$ uniwersalnością faktyczną. Ten cel określa religijne zadanie spoczywające na cesarzu chrześcijańskim do którego, jak do refrenu powraca Euzebiusz - a mianowicie zadanie oczyszczenia ludzkości ze czci oddawanej demonom i bezbożności, wyzwolenie jej od bałwochwalstwa i politeizmu, doprowadzenie jej do poznania prawdziwego Boga i do tej pobożności, ze względu na którą został wybrany przez Boga na cesarza. Cesarz jest w ten sposób narzędziem Boga w stosunku do świata ze względu na Królestwo Boże, wchodząc tym samym w historyczne urzeczywistnianie się Bożego zamysłu zbawienia. $Z$ tego względu cesarz zostaje uznany przez Euzebiusza za głowę Kościoła, czyli za "cesarza chrześcijańskiego" w pełnym znaczeniu tego słowa, a Kościół zostaje utożsamiony z cesarstwem ${ }^{24}$.

\footnotetext{
${ }^{20}$ Por. tamże, I 24; I 41, 2; IV 29, 4.

${ }^{21}$ Por. De laudibus Constantini 6.

${ }^{22}$ Por. De vita Constantini I 1, 3. 4. 6; II 24, 1; IV 62, 4; IV 67, 3; IV 68, 2; IV 69, 2.

23 Por. tamże I 26; II 19, 1.

${ }^{24}$ Por. Farina, L'impero e imperatore, s. 236-251.
} 
Z tego, co zostało tu powiedziane wynika, że relacja miedzy LogosemChrystusem i cesarzem jest obrazem - eikon relacji między Ojcem i LogosemChrystusem. Co więcej, jak Logos jest syntronos Ojca i przygotowuje $\mathrm{Mu}$ Królestwo na koniec czasów, tak cesarz będzie królował z Chrystusem w niebie na wieki oraz doprowadzi do uniwersalności Jego Królestwo na ziemi ${ }^{25}$. Władzę cesarza i jego funkcję zastępczą na ziemi dobrze określa wyrażenie, które później stało się klasyczne, a mianowicie - jest on władcą Dei gratia. Wprawdzie Euzebiusz nie używa jeszcze tego określenia w sensie technicznym, ale idea zawierająca się $w$ tym określeniu jest oddana wlaściwie $z$ najmnicjszymi detalami. Widać ją w syntetycznym opisie złotej monety, jaką kazał wybić Konstantyn:

..Wybito nawet monety $\mathrm{z}$ jego obrazem. $\mathrm{Z}$ jednej strony przedstawiały cesarza z odkrytą głową, a $z$ drugiej ukazywaly go jako woźnicę na kwadrydze, uniesionego ręką, która z góry wyciąga się ku niemu"26.

Wraz z faktem, że przekazanie wladzy przez Ojca cesarzowi za pośrednictwem Chrystusa jest czymś więcej niż tylko prostym przekazaniem władzy w linii następstw na tronic, powstaje coś w rodzaju więzi religijnej między cesarzem a Bogiem, w wyniku czego zostaje jakby ustanawiana „nowa Trójca": Ojciec - Logos - cesarz. Można więc, za R. Fariną, powiedzieć, że chodzi tutaj o "Trójcę królewską"27. Jeśli dodamy do tego rozmaite tytuły, jakie Euzebiusz nadaje cesarzowi, jak: „słońce” i ,światło"28, „,wieczny”, „zwycięzca”, „nowy Mojżesz”, „,biskup powszechny”29, a zwłaszcza te, które dotyczą jego relacji z Bogiem, jak na przyklad „przyjaciel Boga"30, „sługa Boży"31, „wikariusz Boga i Chrystusa"32, a także „blogosławiony”,33 "i „święty”,34, to mamy tutaj nie tylko do czynienia $z$ chrystianizacją pozycji cesarza, ale także ze skrajną sakralizacją zarówno urzędu, jak i osoby ${ }^{35}$.

2. Cesarz jako mimesis Logosu-Chrystusa Króla. Mimesis - naśladowanie, obejmuje przede wszystkim pojęcie obowiązku i za podmiot może mieć tylko

\footnotetext{
${ }^{25}$ Por. Demonstratio evangelica IV 15, 39; V 3, 9; VI 13, 2-3; De ecclesiastica theologia I 11, 5.

26. De vita Constantini IV 73, PG 20, 1228B.

${ }^{27}$ Por. Farina, L'impero e imperatore, s. 239.

28 Por. De vita Constantini I 43, 3.

29 Tytuł ten jest najbardziej dwuznacznym wśród tytułów nadanych Konstantynowi przez
} Euzebiusza, który w ciągu wieków stał się powodem wielu nadinterpretacji - por. R. Farina, "Epískopos tón ektós” (Eusebio, „De vita Const.” IV 24), „Salesianum” 29 (1967) 409-413.

${ }^{30}$ Por. De vita Constantini I 38, 2; IV 46.

${ }^{31}$ Por. tamże, I 3, 1; II 2, 3; IV 14; IV 71, 2.

${ }^{32}$ Por. De laudibus Constantini $7,13$.

${ }_{33}$ Por. De vita Constantini IV 18, 2; IV 67, 3; IV 69, 1; IV 71, 1; IV 73.

${ }^{34}$ Por. tamże, I 9, 2; I 11, 2; IV 67, 3; IV 69, 1; IV 71, 1; IV 73.

${ }^{35}$ Por. Farina, L'impero e imperatore, s. 123. 
cesarza $^{36}$. Jak Chrystus przygotowuje Królestwo Ojcu, tak cesarz propaguje Królestwo Chrystusa na ziemi; jak Chrystus zwyciężył szatana, tak cesarz zwycięża nieprzyjaciół prawdy. Cesarz, naśladując Chrystusa, staje się orędownikiem prawdziwego poznania Boga i Królestwa Bòżego. Chrystus wprowadza ludzi do Królestwa Ojca, cesarz - naśladując Go - oczyszcza świat z pierwotnego blędu, a tym samym wprowadza ludzi do Kościoła, troszcząc się o ich zbawienie. Jest więc wspólnym dobrem udzielonym przez Boga ludzkości ${ }^{37}$.

Cesarz, wybrany przez Logos, by wziąć na siebie obraz (eikon) królowania Ojca, na mocy swojego urzędu jest zobowiązany do ,naśladowania” Chrystusa. Naśladując Chrystusa, który jest doskonałym obrazem Ojca, cesarz chrześcijański będzie mógl osiągnąć doskonalość, która czyni go obrazem królowania $\mathrm{Ojca}^{38}$. Jest on świadomy tego obowiązku, a zarazem - z drugiej strony - jest świadomy nieskończonej wyższości ,prawdziwego Królestwa niebieskiego"; on rządzi jego obrazem ziemskim i dlatego ma w sobie ożywiać pragnienie Królestwa niebieskiego. Dlatego to pierwszą cnotą władcy ma być „pobożność, stanowiąca „,centralne pojęcie w De vita Constantini, ${ }^{39}$.

Ośrodkiem naśladowania, do którego zobowiązany jest cesarz, oraz jego jedynym przedmiotem i jedynym wzorem jest - według Euzebiusza - LogosChrystus. Mimo że wizja chrystologiczna Euzebiusza jest zdominowana wątkiem kosmologicznym, a nie soteriologicznym, jak u innych Ojców i pisarzy kościelnych tego okresu, to trzeba zauważyć, że tutaj została doceniona osoba Chrystusa jako takiego. Archetypem naśladowania nie jest więc ani Ojciec, ani Logos, ale Logos-Chrystus ${ }^{40}$.

Pojęcie obrazu jest stosowane przez Euzebiusza nie tylko w odniesieniu do cesarstwa chrześcijańskiego jako obrazu Królestwa niebieskiego i do cesarza jako obrazu Ojca, ale także do wyrażenia relacji miedzy Ojcem i LogosemChrystusem. Analogicznie mimesis oznacza zarówno naśladowanie relacji między Logosem-Chrystusem i Ojcem, do którego jest zobowiązany cesarz chrześcijański w swoim odniesieniu do Logosu-Chrystusa, jak również oznacza naśladowanie osoby Logosu-Chrystusa.

Cesarz chrześcijański w swoim odniesieniu do Logosu-Chrystusa naśladuje relację zachodzącą miedzy Logosem i Ojcem: Logos przygotowuje Królestwo Ojcu, cesarz przygotowuje Królestwo Logosowi. Cesarz bowiem, naśladując Logos, zwalcza szatana i jego zwolenników - heretyków, oczyszcza cesarstwo z błędu, wzywa caly rodzaj ludzki do poznania Boga, glosi publicznie chrześ-

${ }^{36}$ Doktryna mimesis w odniesieniu do cesarza, jest szczegółowo przedstawiona przez Euzebiusza w: De laudibus Constantini 2.

37 Por. De vita Constantini I 41, 2.

38 Por. tamże, IV 29, 4.

${ }^{39}$ Por. Farina, L'impero e imperatore, s. 212.

${ }^{40} \mathrm{Na}$ temat tego wątku w chrystologii Euzebiusza, por. G.H. Williams, Christology and Church-State relations in the Fourth Centry, ChH 20 (1951) nr 3, 3-33. 
cijaństwo, oraz popiera je i broni ${ }^{41}$. Cesarz naśladuje więc przygotowanie, jakiego dokonuje Logos w stosunku do Królestwa Ojca, sam przygotowując to Królestwo, to znaczy troszcząc się o doprowadzenie do ostatecznego utożsamienia między uniwersalnością de iure Królestwa Chrystusa na ziemi i uniwersalnością faktyczną. Właśnie w przygotowaniu, jakiego cesarz dokonuje swoimi działaniami w stosunku do Królestwa Logosu, dochodzi on do doskonałego naśladowania Logosu, obrazu Ojca; a przez to samo cesarz staje się obrazem Ojca, uczestnicząc - tak jak Logos - w królewskości Ojca.

Cesarz aktualizuje ponadto mimesis przez naśladowanie cnót LogosuChrystusa. Logos, wybierając tego, kto będzie musial podjąć zadanie cesarskie, wlewa mu zalążki cnót, aby uczynić go obrazem królewskości Ojca: ma on je zachowywać i rozwijać w sobie, mając stale przed oczami Logos-Chrystusa. Prawdziwym cesarzem jest więc tylko ten, który odtwarza w sobie obraz Ojca, naśladując cnoty Syna. Logos jawi się więc jako wierny obraz Ojca, który cesarz powinien odtwarzać w sobie, dochodząc w ten sposób do ostatecznego utożsamienia się z godnością cesarską, stworzoną przez Logos jako eikon królewskości Ojca ${ }^{42}$. Może to jednak dokonać się tylko za pośrednictwem Logosu, ponieważ - chociaż jest on wyniesiony ponad ludzi - nie może wejść w bezpośredni kontakt z najwyższym Królem.

W De vita Constantini Euzebiusz dokonał wielkiej systematyzacji elementów chrześcijańskich i pogańskich składających się na wizję cesarza i cesarstwa, z których wyrosła pierwsza teologiczna wizja władcy chrześcijańskiego. Najbardziej charakterystyczną cechą tego ujęcia jest „sakralizacja” władcy i spełnianego przez niego urzędu. Wprawdzie nie jest ona całkowicie jednoznaczna, gdyż ciągle ściera się z jego „świeckością”, ale ostatecznie czynnikiem dominującym i determinującym w tej wizji staje się sakralność. Ma ona swoje źródło zarówno w doktrynie chrześcijańskiej, jak i w doktrynie rzymskiej. Euzebiusz nie zdołał więc uniknąć zawężeń i ideologizacji w swoim ujęciu, ponieważ przede wszystkim zabrakło mu w tej kwestii, bądź co bądź wielkiemu egzegecie, właśnie wrażliwości egzegetycznej, jak zauważył Erik Peterson, wielki znawca kwestii politycznych w odniesieniu do pierwotnego chrześcijaństwa. Wizja wladcy, zaprezentowana przez Euzebiusza, musi być jednak przedmiotem dalszych analiz i podejmowania krytycznych prób oczyszczenia, ponieważ dla chrześcijaństwa wschodniego pozostaje wciąż punktem odniesienia w ramach jego teologii politycznej. W każdym jednak razie Euzebiusz pozostaje pierwszym teologiem politycznym chrześcijaństwa.

\footnotetext{
${ }^{41}$ Por. De vita Constantini III 74.

${ }^{42}$ Por, tamże, IV 29, 4.
} 


\section{LA TENSIONE TRA MONDANITÀ E SACRALITÀ NELLA VISIONE DELL'IMPERATORE NELLA DE VITA CONSTANTINI DI EUSEBIO DI CESAREA}

(Riassunto)

Nella De vita Constantini Eusebio di Cesarea ha realizzato una grande sistematizzazione degli elementi cristiani e pagani riguardanti la visione dell'imperatore e dell'impero, dalla quale - in conseguenza - è sorta la prima visione teologica dell'imperatore cristiano. Una caratteristica specifica di questa visione consiste nella sacralizzazione dell'imperatore e del suo ufficio. Essa non è del tutto univoca poiché si confronta continuamente con la sua mondanità ma - in fin dei conti - il suo elemento dominante e determinante diventa la sacralità. Le sue fonti si trovano sia nella dottrina cristiana che in quella pagana. Eusebio non è riuscito di evitare l'ideologizzazione nella sua impostazione poiché ha trascurato in questa questione nonostante fosse un grande esegeta - la sensibilità esegetica. La visione di Eusebio dovrebbe essere l'oggetto delle ulteriori ricerche e delle purificazioni poiché continuamente rimane il punto di riferimento del cristianesimo orientale nella sua teologia politica. In ogni caso Eusebio continua ad essere il primo teologo politico del cristianesimo. 